Article

\title{
Convergent Synthesis of Thioether Containing Peptides
}

\author{
Spyridon Mourtas ${ }^{1,2}$, Christina Katakalou ${ }^{1}$, Dimitrios Gatos ${ }^{1}$ and Kleomenis Barlos ${ }^{1,3, *}$ \\ 1 Department of Chemistry, University of Patras, 26510 Rio Patras, Greece; s.mourtas@upatras.gr (S.M.); \\ c.katakalou@yahoo.gr (C.K.); d.gatos@upatras.gr (D.G.) \\ 2 Institute of Chemical Engineering Sciences of the Foundation for Research and Technology \\ Hellas (FORTH/IEC-HT), 26504 Rio Patras, Greece \\ 3 CBL-Patras, Patras Industrial Area, Block 1, 25018 Patras, Greece \\ * Correspondence: barlos@cblpatras.gr; Tel.: +30-2610-647600; Fax: +30-2610-647316
}

Academic Editor: Theodore Tselios

Received: 23 December 2019; Accepted: 3 January 2020; Published: 5 January 2020

check for updates

\begin{abstract}
Thioether containing peptides were obtained following three synthetic routes. In route A, halo acids esterified on 2-chlorotrityl(Cltr) resin were reacted with $\mathrm{N}$-fluorenylmethoxycarbonyl (Fmoc) aminothiols. These were either cleaved from the resin to the corresponding (Fmoc-aminothiol) carboxylic acids, which were used as key building blocks in solid phase peptide synthesis (SPPS), or the $\mathrm{N}$-Fmoc group was deprotected and peptide chains were elongated by standard SPPS. The obtained $\mathrm{N}$-Fmoc protected thioether containing peptides were then condensed either in solution, or on solid support, with the appropriate amino components of peptides. In route B, the thioether containing peptides were obtained by the reaction of $\mathrm{N}$-Fmoc aminothiols with bromoacetylated peptides, which were synthesized on Cltr-resin, followed by removal of the $\mathrm{N}$-Fmoc group and subsequent peptide elongation by standard SPPS. In route $C$, the thioether containing peptides were obtained by the condensation of a haloacylated peptide synthesized on Cltr-resin and a thiol-peptide synthesized either on 4-methoxytrityl(Mmt) or trityl(Trt) resin.
\end{abstract}

Keywords: haloacylated peptides; aminothiols; bis(aminoalkyl)dithiols; convergent solid phase peptide synthesis; trityl-type resins

\section{Introduction}

Peptides are used as therapeutic agents for controlling diseases related to peptide functions. However, the use of native peptides for clinical applications has been hampered mainly by their rapid degradation by proteases, poor oral bioavailability, difficult transportation through cell membranes and nonselective receptor binding [1]. These limitations of peptides have led to the synthesis of peptidomimetics through numerous modifications of peptide structures [2-4]. Among the several peptide modifications, isosteric replacement of a peptide bond represents a viable approach in the rational design of peptidomimetics. Peptidomimetics in which the peptide amide bond is replaced by ethylene (1a)-, methyleneimino (1b)-, methyleneoxy (1c)- and methylenethio (1d)-groups (Figure 1) were found to exhibit potential pharmaceutical application [4-15]. Such modifications alter the physical and chemical properties of the native peptide, reducing its peptide character and leading to peptide analogues with increased resistance to proteolytic enzymes, flexibility and lipophilicity, while they also confer diverse electrostatic properties and new secondary conformations on the peptidomimetic chain, often resulting in improved pharmacokinetic properties $[2,16,17]$. 


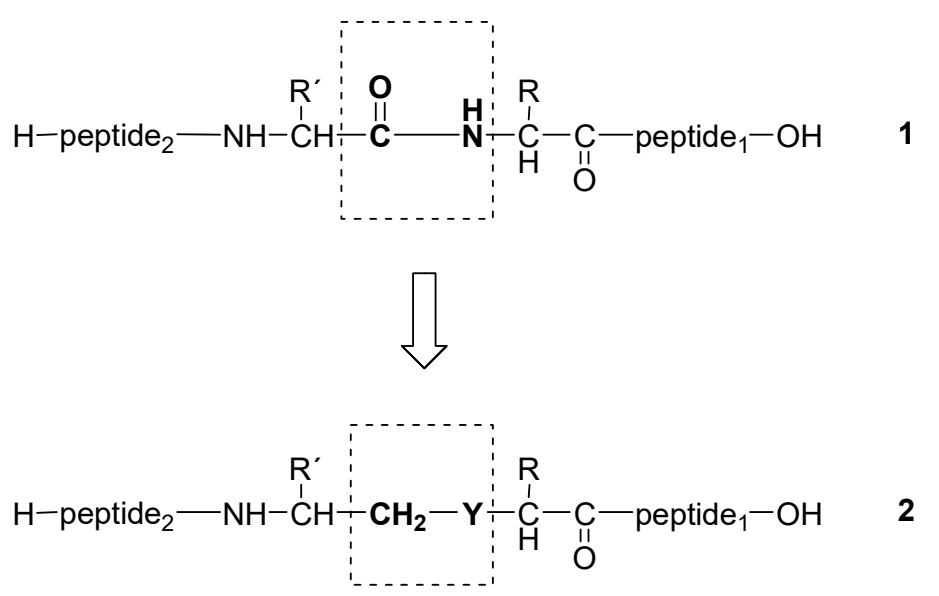

Figure 1. Peptide bond isosteres: $\mathrm{Y}=\mathrm{CH}_{2}(\mathrm{a}), \mathrm{NH}(\mathrm{b}), \mathrm{O}(\mathrm{c})$ and $\mathrm{S}(\mathrm{d})$.

Solid-phase synthesis (SPS) is a common technique for peptide synthesis. The classical step-by-step solid-phase peptide synthesis (SPPS) is a well-established methodology for the synthesis of small to medium-sized peptides [18]. Besides SPPS, the convergent solid-phase peptide synthesis (CSPPS) has been developed for the preparation of larger and/or complex peptides and proteins [19-24], based on the fact that no directional restrictions exist in CSPPS and the chain elongation can be performed with equal possibility of success to any direction. CSPPS methods include fragment condensation such as the solid- or solution-phase based protocols. Both methods consist of the rational and retro-synthetic detachment of segments in the native sequence, which in a synthetic flow would be connected in the appropriate manner in the solid- or in the solution-phase.

The very acid labile 2-chlorotrityl (Cltr) resin [25] and the Fmoc/ ${ }^{t} \mathrm{Bu}$ methodology $[23,26]$ have been developed and widely used for SPPS and CSPPS of protected peptides. In general the sequential condensation of fluorenylmethoxycarbonyl (Fmoc)/tert-butyl $\left({ }^{\mathrm{t}} \mathrm{Bu}\right)$ protected peptide fragments on a solid support to larger peptides (convergent synthesis, solid phase fragment condensation (SPFC)) is a simple method for the preparation of large or difficult peptides by convergent methods [27,28]. The main limitation of this method is that, in some cases, the $\mathrm{N}$-Fmoc deprotection of the resin-bound peptide and the subsequent condensation with the next fragment proceeds slowly and incomplete. A solution to this problem is provided with the cleavage of the protected peptide from the resin in order to perform the $\mathrm{N}$-Fmoc removal and the condensation in solution. This type of condensation is also advantageous from an economical point of view, since the $\mathrm{C}$ - and $\mathrm{N}$-components are used in equimolar amounts. The key step of this method is the esterification of the protected peptide, which is cleaved from the resin, at the C-terminal carboxyl function, and for this reason, the usefulness of 2-chlorotrityl chloride monomer as a temporary carboxy-protecting group has been studied in CSPPS [24].

In this manuscript, we describe our efforts in the synthesis of peptidomimetics of type 2 (Figure 1), by using simple methods of CSPPS. In particular, we describe three methods in the convergent synthesis of type $2 \mathbf{d}$ peptide isosteres, in which the amide bond is replaced by $\mathrm{CH}_{2}-\mathrm{S}$ isostere bond (thioether bond), using methods of solid phase peptide fragment condensation or solution fragment condensation through the formation of an amide bond, and the condensation of two fragments through the formation of a thioether bond.

\section{Results and Discussion}

In an effort to apply standard methods of convergent solid phase peptide synthesis (CSPPS) $[21,24,26]$ in the preparation of the thioether containing peptides 11 (Scheme 1), we esterified the halo acids 3 with 2-chlorotrityl(Cltr) resin 4 in dichloromethane (DCM) using $\mathrm{N}, \mathrm{N}$-diisopropylethylamine (DIPEA) as the hydrogen halide acceptor. The reaction proceeds fast independently from the bulkiness of 3 and resins containing $0.6-1.0 \mathrm{mmol} \mathrm{3/g}$ were obtained. The loading of the resins 5 was determined by Gas Chromatography (GC) after cleavage of the 
haloacids by treatment of resin probes with 3\% trifluoroacetic acid (TFA) in DCM for 30 min at room temperature. The obtained haloacid derivatives 5 were further reacted with a two-fold molar excess of the $N$-fluorenylmethoxycarbonyl (Fmoc) aminothiols 6 [29] and DIPEA in dimethylformamide (DMF) for 1-12 h at room temperature. Especially the more electrophilic $\alpha$-haloacids, such as the bromoacetic acid, react very fast with the less hindered Fmoc-aminothiols 6 (in less than 30 min) to the resin-bound ( $N$-Fmoc aminothiol)carboxylic ester 7 . Treatment of 7 with the cleavage mixture acetic acid $(\mathrm{AcOH})$ /trifluoroethanol (TFE)/dichloromethane (DCM) (1:2:7) for $30 \mathrm{~min}$ at room temperature followed by extractive work up gave the key building blocks 8 , which were applied in usual step by step solid phase peptide synthesis (SPPS), by Fmoc/tert-butyl ( ${ }^{\mathrm{t}} \mathrm{Bu}$ ) methodology leading to the target peptides 11. Instead of using 8 in SPPS, direct peptide elongation on resin 7 , by standard SPPS and cleavage from Cltr-resin by the cleavage mixture AcOH/TFE/DCM (1:2:7) gave the thiol-containing peptide 9. The obtained segment 9 can be condensed with the amino components of the peptide fragment 10 either in solution (in case of $O$-Cltr protected peptide fragment 10a) [24] by using solution fragment condensation strategy, or in solid phase (in case of resin-bound peptide fragments $\mathbf{1 0 b}$ ). In the first case, fragment condensation of 9 with the $O$-Cltr protected monomer 10a requires an equimolar amount of $\mathbf{9}$, while in the second case condensation of $\mathbf{9}$ with the $N$-free amino group of peptides attached on the Cltr-resin $\mathbf{1 0 b}$ requires a two-fold molar excess of $\mathbf{9}$ to be completed.

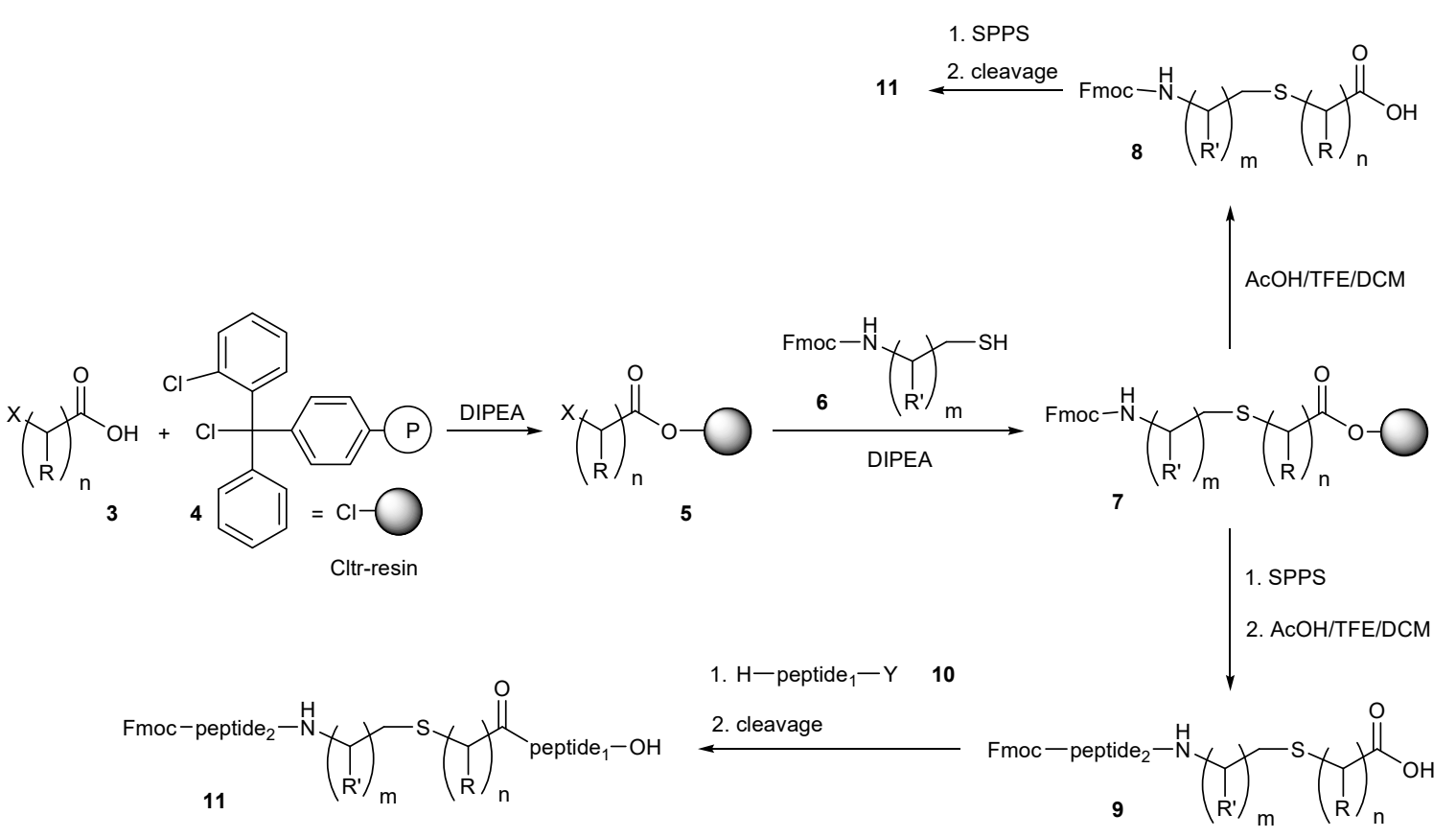

Scheme 1. Route A for convergent solid-phase peptide synthesis (CSPPS) of thioether containing peptides. Halo acids esterified on Cltr-resin were reacted with $\mathrm{N}$-Fmoc aminothiols and peptide chains were elongated either by direct SPPS or CSPPS, or cleavage of the (Fmoc-aminothiol)carboxylic acids and their use in SPPS; $\mathrm{R}=\mathrm{H}(\mathrm{n}=1-5), \mathrm{CH}_{3}(\mathrm{n}=1) ; \mathrm{R}^{\prime}=\mathrm{H}(\mathrm{m}=1-5), \mathrm{CH}_{3}, \mathrm{CH}\left(\mathrm{CH}_{3}\right)_{2}, \mathrm{CH}_{2} \mathrm{CH}\left(\mathrm{CH}_{3}\right)_{2}$, $\mathrm{CH}\left(\mathrm{CH}_{3}\right) \mathrm{CH}_{2} \mathrm{CH}_{3}, \mathrm{CH}_{2}\left(\mathrm{C}_{6} \mathrm{H}_{5}\right)(\mathrm{m}=1) ; \mathrm{X}=\mathrm{Cl}, \mathrm{Br} ; \mathrm{Y}=\mathrm{O}$-Cltr monomer (10a), O-Cltr-resin (10b).

By applying a similar method, esterification of the halo acid 3 with the $N$-free amino group of peptides elongated on Cltr-resin gave the resin-bound haloacylated peptide $\mathbf{1 2}$ (Scheme 2). For this synthesis step by step SPPS (Fmoc/t Bu methodology) was used. The resin-bound haloacylated peptide 12 was then condensed with a two-fold molar excess of the N-Fmoc aminothiol 6 and DIPEA in DMF for $1-12 \mathrm{~h}$ at room temperature to the resin-bound peptide 13. Removal of the N-Fmoc group by piperidine liberated the amino group of the peptide chain, enabling the peptide elongation either by standard SPPS or by CSPPS using the N-Fmoc protected peptide fragment 14 . The obtained 
resin-bound thiol-containing peptide 15 was finally treated with the cleavage mixture AcOH/TFE/DCM (1:2:7) to the thioether containing peptide 11.
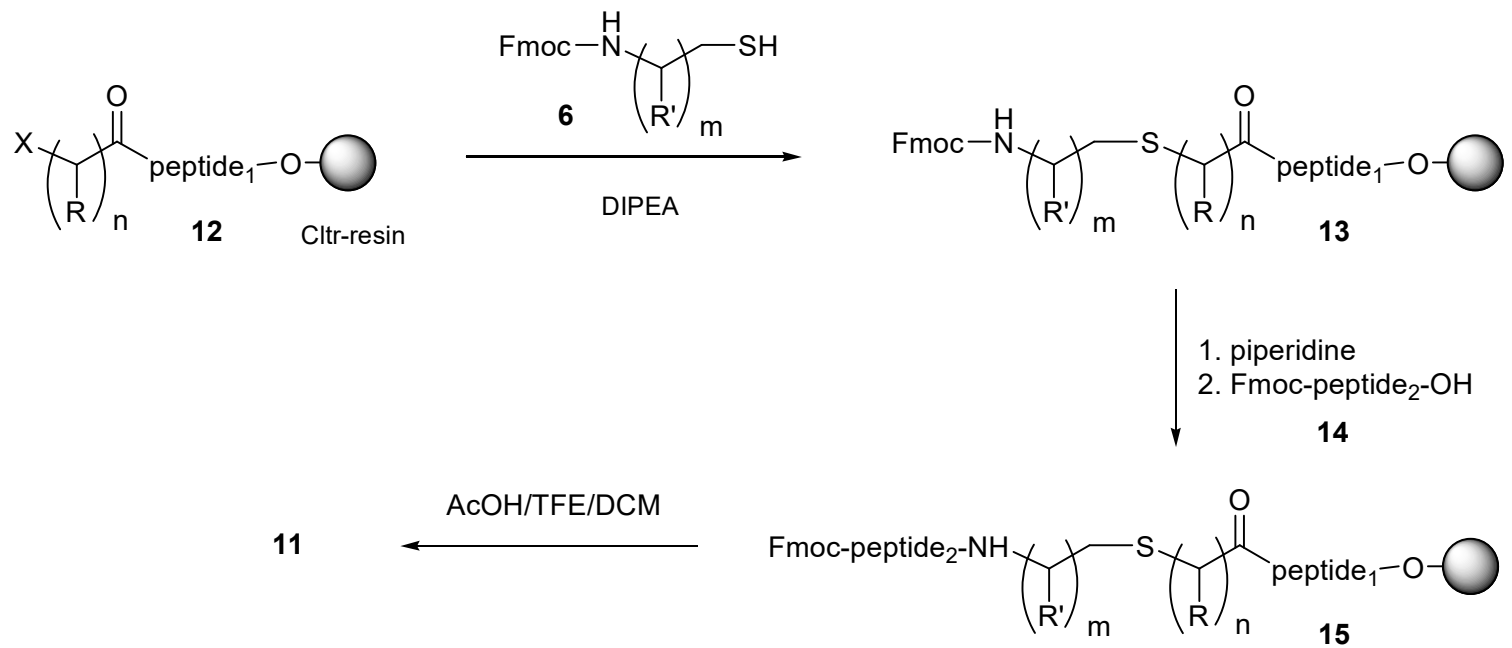

Scheme 2. Route B for CSPPS of thioether containing peptides. The thioether containing peptides were obtained by the reaction of $\mathrm{N}$-Fmoc aminothiols with bromoacetylated peptides, which were synthesized on Cltr resin, followed by removal of the $\mathrm{N}$-Fmoc group and peptide elongation; $\mathrm{R}=\mathrm{H}$ ( $\mathrm{n}$ $=1-5), \mathrm{CH}_{3}(\mathrm{n}=1) ; \mathrm{R}^{\prime}=\mathrm{H}(\mathrm{m}=1-5), \mathrm{CH}_{3}, \mathrm{CH}\left(\mathrm{CH}_{3}\right)_{2}, \mathrm{CH}_{2} \mathrm{CH}\left(\mathrm{CH}_{3}\right)_{2}, \mathrm{CH}\left(\mathrm{CH}_{3}\right) \mathrm{CH}_{2} \mathrm{CH}_{3}, \mathrm{CH}_{2}\left(\mathrm{C}_{6} \mathrm{H}_{5}\right)$ $(\mathrm{m}=1) ; \mathrm{X}=\mathrm{Cl}, \mathrm{Br}$.

In order to evaluate the applicability of the above described methods in SPPS, we synthesized the simple thiolether containing peptide 16 (by using route A) and $\mathbf{1 7}$ (by using route B; Figure 2). Their synthesis was done on Cltr-resin by using $\mathrm{Fmoc} /{ }^{\mathrm{B}} \mathrm{Bu}$ strategy, according to Schemes 1 and 2 , respectively.

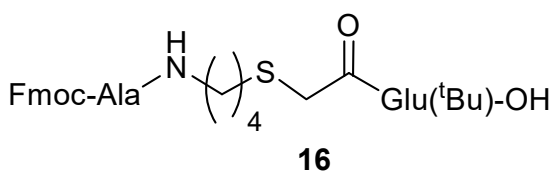

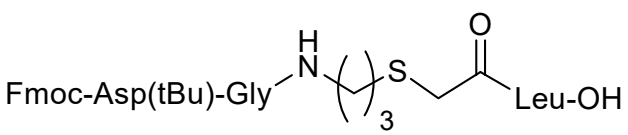

17

Figure 2. Structure of thioether containing peptide $\mathbf{1 6}$ (synthesized by using route A), and $\mathbf{1 7}$ (synthesized by using route B).

In brief, amino acid couplings were achieved by using 1-hydroxybenzotriazole $/ N, N^{\prime}-$ diisopropylcarbodiimide (HOBt/DIC) in N-methyl-2-pyrrolidone (NMP). As the N-Fmoc aminothiols 6, the corresponding $N$-Fmoc aminobutanethiol and $N$-Fmoc aminopropanethiol derivatives were used. Both thioether containing peptides (16 and 17) were prepared in high yield (87 and 90\% yield, respectively) and purity (95 and 98\%, respectively) as confirmed by hplc analysis (see Figure S1 in Supplementary Materials section), revealing that these methods could be used for the preparation of larger thioether containing peptides. The correct mass of peptide analogues $\mathbf{1 6}$ and $\mathbf{1 7}$ was determined by ESI-MS analysis (16: [M + H] calc.: 641.28; found: 641.42 and 17: $[\mathrm{M}+\mathrm{H}]$ calc.: 712.31; found: 712.56). In this method, although the thioether formation between the N-Fmoc aminothiol 6 and the haloacylated peptide 12 proceeds relatively fast, the fragment coupling of the resin-bound $N$-Fmoc deprotected thiol-peptide 13 with the $N$-Fmoc peptide fragment 14, proceeds slowly (6-12 h) and in some cases is incomplete, similarly to route A.

Since the condensation of the different fragments in both routes A (either by using 8 in SPPS, or by fragment coupling between 9 and 10) and B (fragment coupling between the N-Fmoc deprotected 13 and 14) proceeds through amide formation, which is relatively slow, we proposed a third method 
(route C), for the synthesis of thioether containing peptides 11, which enables the fast condensation reaction between two peptide fragments.

In this method (route $C$ ), the synthesis of thioether containing peptides $\mathbf{1 1}$ does not proceed through amide bond formation (as in routes A and B), but through thioether bond formation, by the nucleophilic attack of the $N$-Fmoc protected thiol-peptide 20 with the resin-bound bromoacetylated peptide 12 (Scheme 3). The first step in this procedure is the preparation of the thiol-peptide 20. For this, we used either aminothiols attached on 4-methoxytrityl(Mmt) resin through their thiol function 18 [29], or resin-bound bis(aminoalkyl)dithiol attached on trityl(Trt) resin through their free amino group 19. Peptide elongation was achieved by using standard SPPS (Fmoc/ $/{ }^{t} \mathrm{Bu}$ strategy), while amino acid coupling was achieved by using HOBt/DIC in NMP. The derived resin bound peptides were then quantitatively cleaved with 1\% TFA in presence of DCM/triethylsilane (TES) (95:5) (in case of peptides elongated on resins 18), and dithiothreitol (DTT) or TES (in case of peptides elongated on resins 19), to the $\mathrm{N}$-Fmoc thiol-peptides 20 (Scheme 3). In the next step of the synthesis, the $\mathrm{N}$-Fmoc protected thiol-peptide fragments 20 were condensed with the resin-bound halo acylated peptides $\mathbf{1 2}$ in DMF and DIPEA and the obtained resin-bound thioether peptides were completely cleaved from the Cltr-resin by treatment with AcOH/TFE/DCM (1:2:7) for $15 \mathrm{~min}$ at room temperature. It was noticed that the condensation between the bromoacetylated peptide segments 12 and the $\mathrm{N}$-Fmoc thiol-peptides 20 proceeded with exceptional ease and in some cases very fast (10 $\mathrm{min})$, as it is shown below, in the example of choice (thioether containing peptide 26).

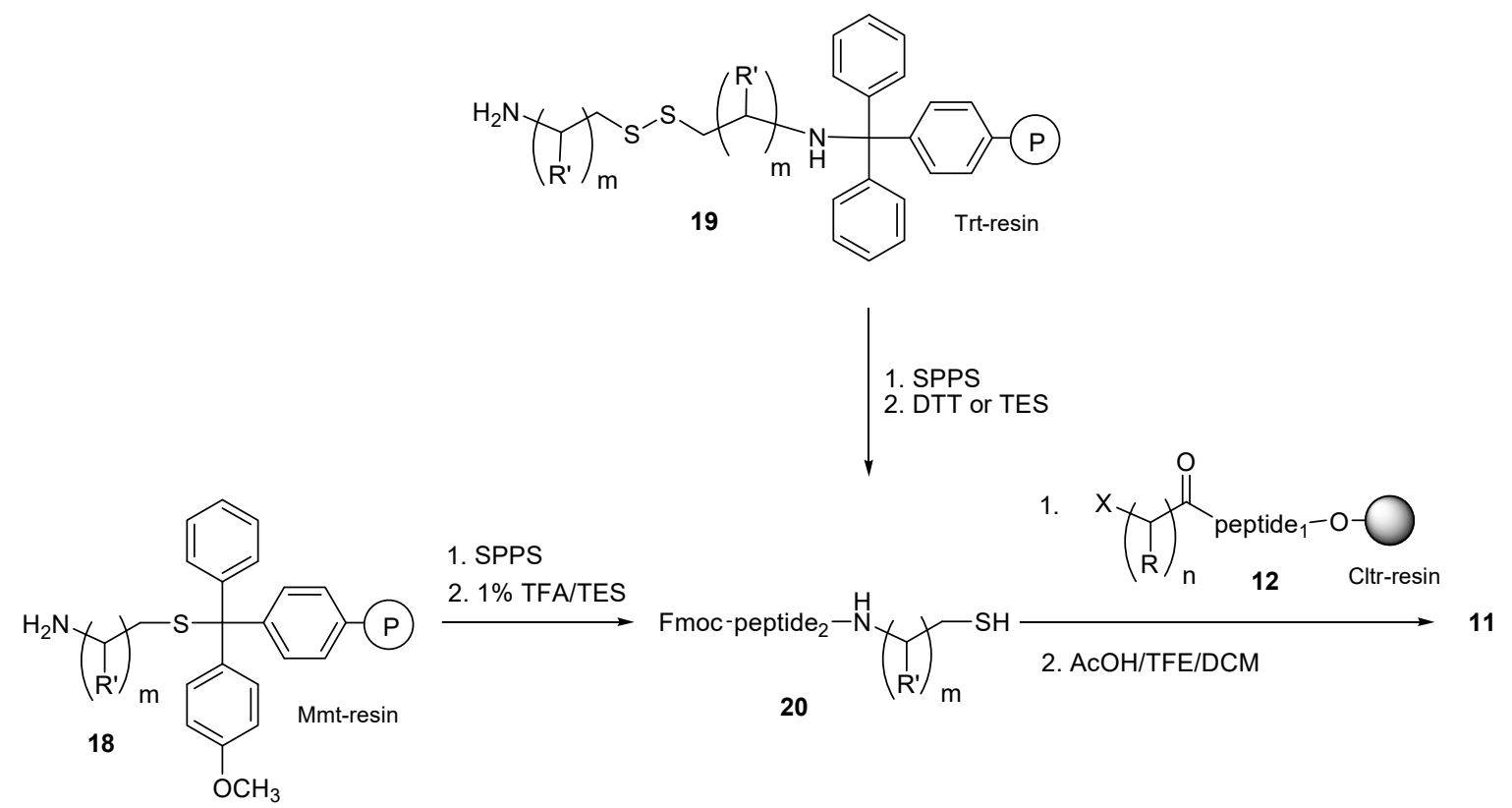

Scheme 3. Route $\mathrm{C}$ for CSPPS of thioether containing peptides. The thioether containing peptides were obtained by the condensation of a haloacylated peptide which was synthesized on Cltr-resin and a thiol-peptide which was synthesized either on Mmt-resin, or on Trt-resin; $\mathrm{R}=\mathrm{H}(\mathrm{n}=1-5), \mathrm{CH}_{3}(\mathrm{n}=1)$; $\mathrm{R}^{\prime}=\mathrm{H}(\mathrm{m}=1-5), \mathrm{CH}_{3}, \mathrm{CH}\left(\mathrm{CH}_{3}\right)_{2}, \mathrm{CH}_{2} \mathrm{CH}\left(\mathrm{CH}_{3}\right)_{2}, \mathrm{CH}\left(\mathrm{CH}_{3}\right) \mathrm{CH}_{2} \mathrm{CH}_{3}, \mathrm{CH}_{2}\left(\mathrm{C}_{6} \mathrm{H}_{5}\right)(\mathrm{m}=1) ; \mathrm{X}=\mathrm{Cl}, \mathrm{Br}$.

Although we have already published the advantages of resin bound aminothiols $\mathbf{1 8}$ (loaded through their thiol group on Mmt-resins) in the synthesis of $\mathrm{N}$-Fmoc thiol-containing peptides [29], the use of bis(aminoalkyl)disulfides bound on Trt-resins 19 (through their amine group) in SPPS is described for the first time. These resins may offer several advantages in SPS, SPPS and CSPPS, based on their ability to form either thiol-peptides by reductive cleavage, or bis(aminoalkyl)thiol peptides by treatment of the resin with 1\% TFA in presence of DCM/TES (95:5). The first case (reductive cleavage of thiol-peptides 20 from resins 19) can be used for the synthesis of the $N$-Fmoc protected thiol-peptides 20, by their treatment with DTT or TES, which are considered as mild reducing agents. 
Thus, in an effort to optimize the cleavage of the thioether containing peptides $\mathbf{1 1}$ synthesized on Trt-resins 19, we compared the use of DTT or TES in terms of yield and purity. For this, the resin-bound bis(aminoalkyl)dithiol derivative $\left(\mathrm{R}^{\prime}=\mathrm{CH}_{3}\right) 19$ was coupled with $\mathrm{N}$-Fmoc-leucine by using HOBt/DIC as the carboxylic acid activator. The derived resin was treated with a 10 fold molar excess of DTT or TES. In both cases the expected Fmoc-Leu-alaninothiol was completely cleaved from the resin after $12 \mathrm{~h}$ reaction at room temperature. Hplc analysis of the crude product showed that the use of TES is superior in terms of product purity, as a purity of $67 \%$ was noticed for the crude product of Fmoc-Leu-alaninothiol cleaved by DTT, while a purity of $98 \%$ was noticed for Fmoc-Leu-alaninothiol cleaved by TES (see Figure S2 in Supplementary Materials section). The correct mass of the released Fmoc-Leu-alaninothiol was determined by ESI-MS analysis ([M $+\mathrm{H}]$ calc.: 427.21; found: 427.32). For this reason, TES was used for the cleavage of the more complicated peptides that were prepared by this route.

As an example of the more complicated thiol-containing peptides that we prepared by the use of resin 19, we describe the synthesis of two thiol-peptide analogues: 21 (Figure 3; synthesized on Trt-resin 19 where $\mathrm{R}^{\prime}=\mathrm{CH}_{3}$ ) and 22 (Figure 3; synthesized on Trt-resin 19 where $\mathrm{R}^{\prime}=-\mathrm{CH}_{2}-\mathrm{Ph}$ ).

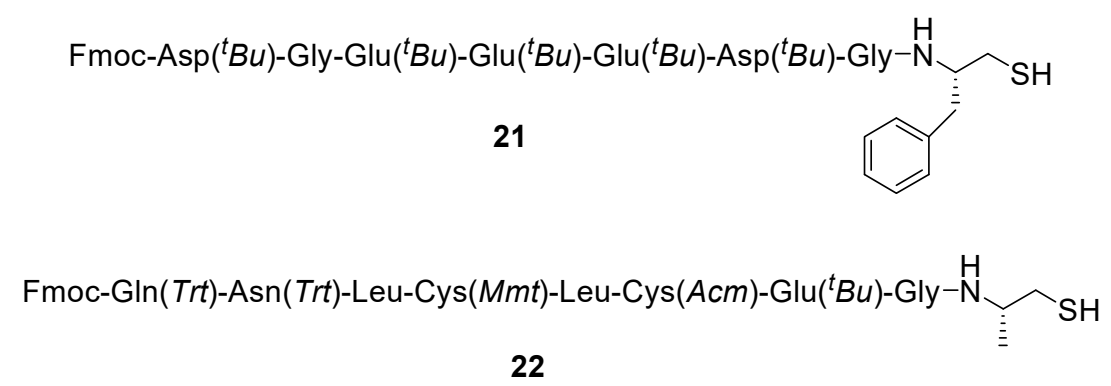

Figure 3. Structure of thiol-peptides 21 (ProTa (69-75) derivative) and 22 (Hirudine (11-18) derivative), synthesized on Trt-resins $19\left(\mathrm{R}^{\prime}=\mathrm{CH}_{3}(\mathbf{2 1}) ;-\mathrm{CH}_{2}-\mathrm{Ph}(22)\right)$.

The first product (peptide structure 21) is a thiol derivative of the prothymosin a peptide sequence (ProTa (69-75)) prepared in high yield (82\%) and purity ( $>98 \%)$, as can be seen by the hplc analysis of the crude product (see Figure S3A in Supplementary Materials section). Its correct mass was determined by ESI-MS analysis (see Figure S3B in Supplementary Materials section): ([M + H] calc.: 1401.69; found: 1401.59). The second product (peptide structure 22) is a peptide derivative of hirudine (Hir (11-18)), which contains two differently protected cysteines: Cys14(Mmt) and Cys16( $\mathrm{Acm})$. By using this resin, we were able to synthesize the thiol-peptide 22, after its cleavage from the Trt resin 19 by TES, without affecting the Cys14(Mmt) protecting group. This product was also prepared in high yield (78\%) and purity $(90 \%)$, as can be seen by the hplc analysis (see Figure S3C in Supplementary Materials section), while its correct mass was determined by ESI-MS: ([M + 2H] calc.: 1029.46; found: 1029.86 (see Figure S3D in Supplementary Materials section)).

As an example of the final step of our strategy for the synthesis of thioether containing peptides 11 by route $C$, we present the synthesis of the cysteamine derivative $\mathbf{2 6}$, which is composed by two prothymosin a segments (ProTa (69-75)) linked by a thioether bond (Scheme 4). For this synthesis, the resin-bound bromoacetylated peptide 23 was initially prepared on Cltr-resin by using standard SPPS methods (Fmoc/t ${ }^{\mathrm{B} u}$ method and HOBt/DIC for the amino acid activation). Then a two-fold molar excess of $\mathbf{2 4}$ was condensed with $\mathbf{2 3}$ in DMF/DIPEA for $10 \mathrm{~min}$ at room temperature (Scheme 4). The resin $\mathbf{2 5}$ was treated with AcOH/TFE/DCM (1:2:7) and the protected peptide $\mathbf{2 6}$ was obtained in $90 \%$ yield and $92 \%$ purity according to HPLC analysis (see Figure S4 in Supplementary Materials section). The correct mass of the obtained peptide $\mathbf{2 6}$ was determined by ES-MS analysis $([\mathrm{M}+2 \mathrm{H}]$ calc.: 1191.60; found: 1191.80). 


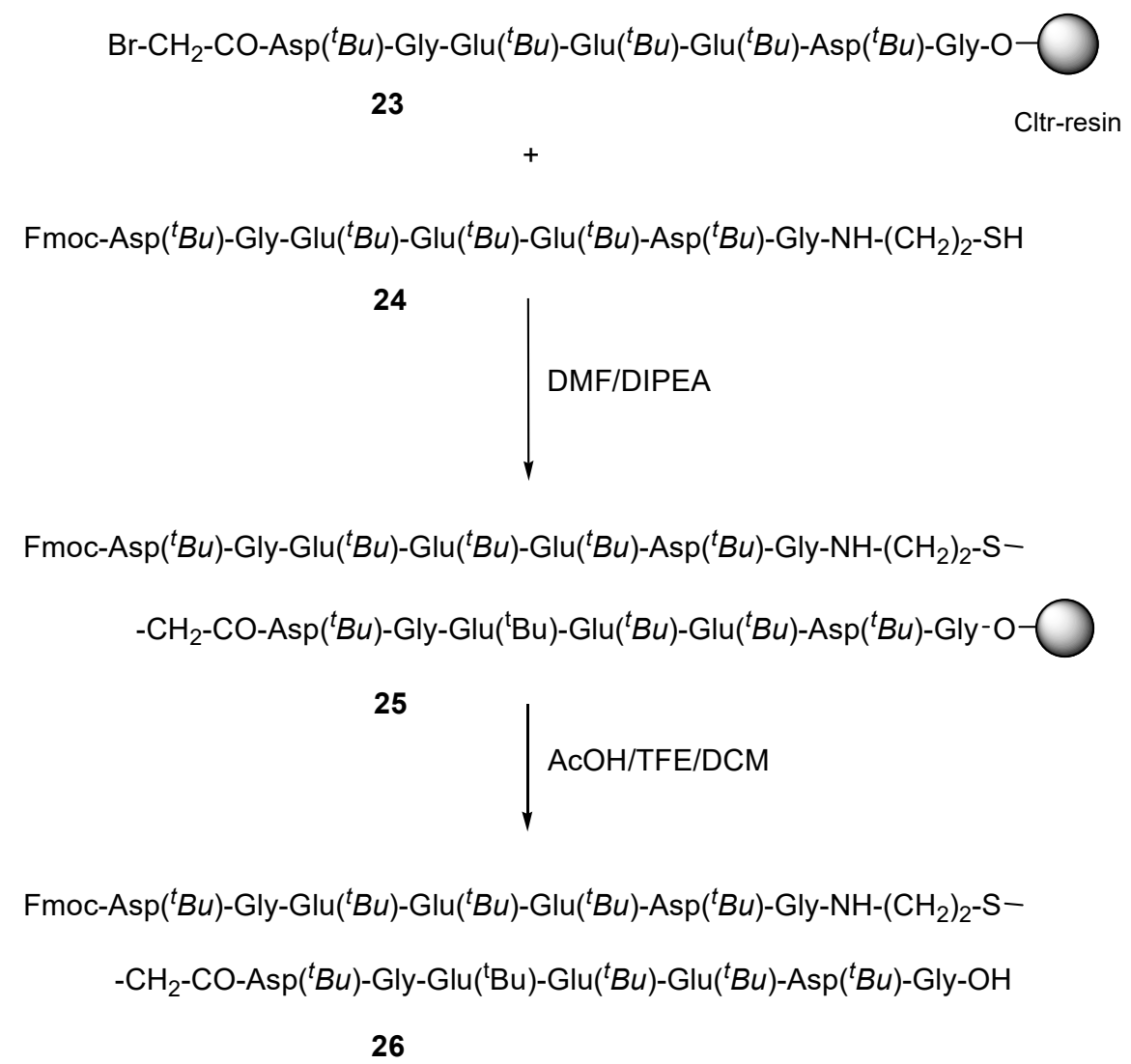

Scheme 4. Synthetic procedure of 26 by using route C.

Ligation strategies on haloacylated peptides have been found to proceed very fast in case of bromoacylated peptides, while in case of chloroacylated peptides moderate reactivities were found $[30,31]$. In order to examine this parameter, we planned the fragment condensation of thiol-peptides to chloroacylated peptides. As an example we synthesized the somatostatin analogue (6-14) where Cys14 was replaced by cysteamine (Cys ; 2 -aminoethanethiol) 27. In this experiment, the thiol-peptide 27 contains the acid sensitive $\operatorname{Ser}(\operatorname{Tr} t)(O-\operatorname{Tr} t$ is cleaved by $1 \%$ TFA) and for this reason it was synthesized on Trt-resin 19. The thiol-peptide 27 was condensed with the 4-chloromethylbenzoyl-Leu-O-Cltr resin 28 (Scheme 5) in a 1.5:1 molar ratio in DMF and DIPEA and the reaction process was followed by hplc analysis, after the treatment of resin probes with $\mathrm{AcOH} / \mathrm{TFE} / \mathrm{DCM}$ (1:2:7) for $15 \mathrm{~min}$ at room temperature, by which the desired product 30 and the un-reacted 31 were identified. Analysis of the hplc chromatograms (see Figure S5 in Supplementary Materials section) showed a high percentage of un-reacted 31 (absorbance ratios of 30/31: 46/54) after $2 \mathrm{~h}$ reaction time, due to incomplete reaction of $\mathbf{2 7}$ with $\mathbf{2 8}$, while a significant percentage of 31 (absorbance ratios of 30/31: 82/18) was still observed even after $24 \mathrm{~h}$ reaction. It should be noted that, although the reaction progress was rather slow, no significant by-products were detected during the extended reaction time. Product 30 was identified by ESI-MS ([M - Trt $+2 \mathrm{H}]$ calc.: 902.46; found: 903.38; (see Figure S5 in Supplementary Materials section). 
Fmoc-Phe-Phe-Trp-Lys (Boc)-Thr $\left({ }^{t} B u\right)-\mathrm{Phe}-\operatorname{Thr}\left({ }^{t} B u\right)-\operatorname{Ser}(\operatorname{Trt})-\mathrm{Cys}_{\mathrm{a}}-\mathrm{SH}$

27<smiles>O=C(Cl)C(=O)Oc1ccccc1</smiles><smiles>O=C(c1ccc(CCl)cc1)C(O)O</smiles>

Fmoc-Phe-Phe-Trp-Lys(Boc)-Thr $\left({ }^{t} B u\right)$ Phe-Thr $\left({ }^{t} B u\right)-\operatorname{Ser}(T r t)-C y s_{a}-S$<smiles>CC(C)(C)SCc1ccc(C(=O)C(C)(C)C)cc1</smiles>

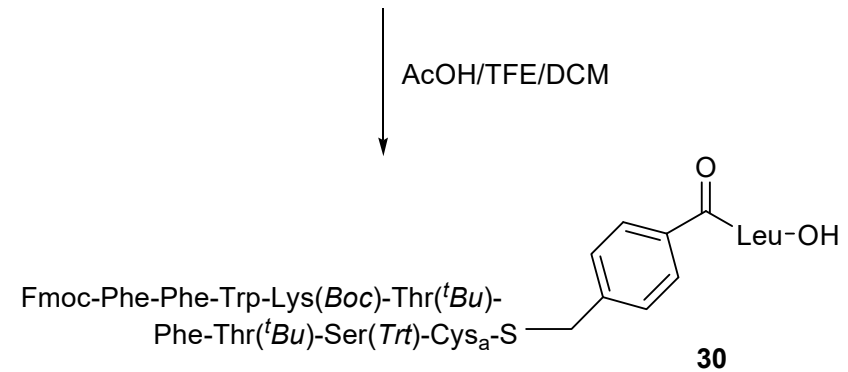

Scheme 5. Synthetic procedure of $\mathbf{3 0}$ by using route $\mathrm{C}$. The reaction process was monitored by hplc analysis following the peaks of the desired product $\mathbf{3 0}$ and un-reacted $\mathbf{3 1}$ after their cleavage from the resin (see Figure S5 in Supplementary Materials section).

In case of haloacetyl-peptides, which contain various strong nucleophiles, one should be aware of possible side reactions of the nucleophiles with the haloacetyl moiety. This is a well-known problem especially for bromoacetylated-methionine (Met)-peptides [31-33]. In this work we found similar instability issues for bromoacetylated-proline (Pro)-peptides. As an example, resin-bound MUC-1 32 was treated with piperidine to liberate the $\mathrm{N}$-terminus of the peptide sequence and this was reacted with a three-fold molar excess bromoacetic acid and DIC in NMP (Scheme 6). After cleavage of the obtained peptide from the resin and deprotection with TFA/water (95:5) for $3 \mathrm{~h}$ at room temperature, the main product of the synthesis, instead of the expected haloacylated peptide, was a product with a molecular mass [M -81$]([\mathrm{M}-81+2 \mathrm{H}]$ : calc.: 963.97; found: 964.09). This corresponds to a peptide with one less $\mathrm{HBr}$, which was attributed to the diketopiperazine peptide derivative 35, obviously prepared by the nucleophilic attack of the $N$-terminus group of alanine to the carbon atom that bears the bromine. This nucleophilic attack is possibly favored by the proximity of these atoms, which is due to the presence of proline just before the haloacid in the peptide chain (Scheme 6). 
Fmoc-Pro-Ala-His(Trt)-Gly-Val-Thr $\left({ }^{t} B u\right)$-Ser(Trt)-Ala-Pro-Asp $\left({ }^{t} B u\right)-\operatorname{Thr}\left({ }^{t} B u\right)$ $\operatorname{Arg}($ Pbf $)$-Pro-Ala-Pro-Gly-Ser(Trt)-Thr('Bu)-Ala-Pro-O

32

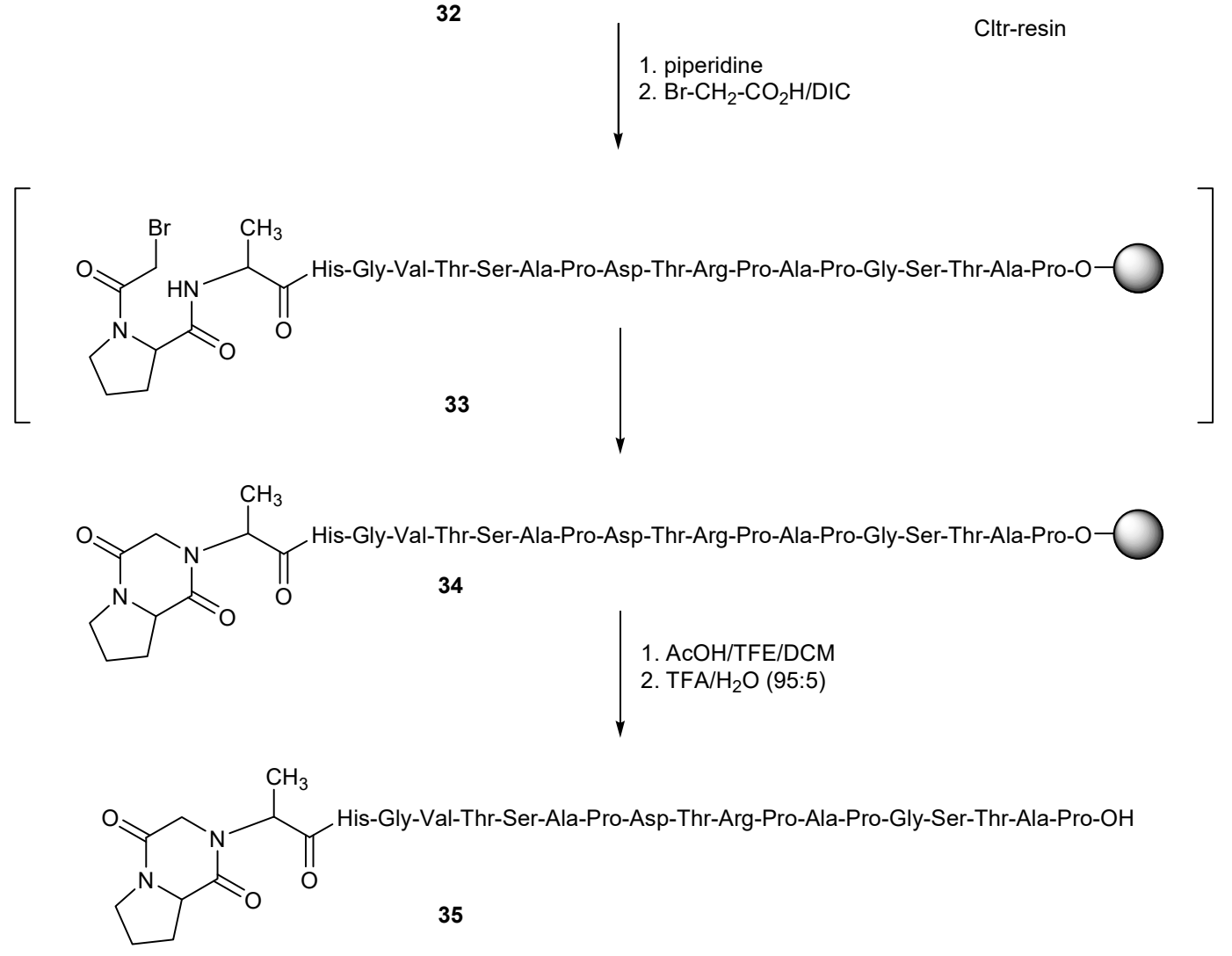

Scheme 6. Diketopiperazine peptide derivative 35 formation of bromoacetylated-MUC-1 peptide.

\section{Materials and Methods}

\subsection{Materials}

All chemicals were purchased from Sigma-Aldrich OM, Athens, Greece, except 2-Chlorotrityl polystyrene (Cltr) resin and Fmoc-protected amino acids, which were gifted from CBL Patras S.A. (Industrial area of Patras, Building block 1, GR-25018, Patras, Greece). All chemicals were used without further purification, according to the manufacturer's instructions and safety precautions. TFA was used in a properly ventilated hood, wearing protective gloves/protective clothing/eye protection/face protection.

\subsection{Analytical Methods}

Thin layer chromatography (TLC) was performed on precoated silica gel 60 F254 plates (Merck, Darmstadt, Germany) and spot detection was carried out by UV light, or by charring with a ninhydrin solution. HPLC analysis was performed on a Waters 600E multisolvent delivery system (Milford, MA, USA), combined with Waters 991 photodiode array detector, using a Nucleosil C8 (4 $\mathrm{mm} \times 125 \mathrm{~mm}$, $7 \mu \mathrm{m}$ ) and a linear gradient from 50 to $100 \%$ acetonitrile (containing $0.1 \%$ TFA) in water (containing $0.1 \%$ TFA) within $30 \mathrm{~min}$ at a flow rate of $1 \mathrm{~mL} / \mathrm{min}$ or Lichroshere RP-8 $(4 \mathrm{~mm} \times 150 \mathrm{~mm}, 5 \mu \mathrm{m})$ and a linear gradient from 20 to 100\% acetonitrile (containing 0.1\% TFA) in water (containing 0.1\% TFA) within $30 \mathrm{~min}$ at a flow rate of $1 \mathrm{~mL} / \mathrm{min}$. Chromatograms were detected at $265 \mathrm{~nm}$. ES-MS spectra were recorded on a Micromass Platform L.C. (Manchester, UK) at 30 V. 


\subsection{Synthetic Procedures}

\subsubsection{General Protocol for the Synthesis of Bis(aminoalkyl)dithiols}

In a solution containing S-trityl (Trt) aminothiols [29] (5.8 mmol, $\mathrm{R}^{\prime}=\mathrm{H}, \mathrm{m}=1: 1.85 \mathrm{~g} ; \mathrm{H}, \mathrm{m}=$

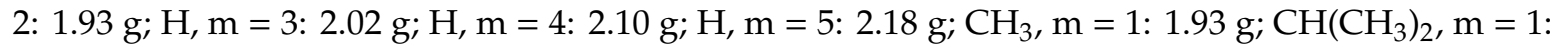
$2.10 \mathrm{~g} ; \mathrm{CH}_{2} \mathrm{CH}\left(\mathrm{CH}_{3}\right)_{2}, \mathrm{~m}=1: 2.18 \mathrm{~g} ; \mathrm{CH}\left(\mathrm{CH}_{3}\right) \mathrm{CH}_{2} \mathrm{CH}_{3}, \mathrm{~m}=1: 2.18 \mathrm{~g} ; \mathrm{CH}_{2}\left(\mathrm{C}_{6} \mathrm{H}_{5}\right)$ and $\left.\mathrm{m}=1: 2.38 \mathrm{~g}\right)$ in tetrahydrofuran (THF; $9 \mathrm{~mL}$ ), 30\% (w/w) hydrogen peroxide $\left(\mathrm{H}_{2} \mathrm{O}_{2}\right)$ was added, drop-by-drop, at room temperature, until the formation of a white solid $(6.0 \mathrm{mmol} ; 0.47 \mathrm{~mL})$. The reaction mixture was left for about $1 \mathrm{~h}$ at room temperature and then condensed under reduced pressure. The oily product was suspended in diethyl ether (DEE) and subjected to extraction in DEE/water. The organic phase was washed twice with water and then dried over $\mathrm{Na}_{2} \mathrm{SO}_{4}$, filtered and condensed. The oily product was dissolved in $4 \mathrm{~mL}$ of dichloromethane (DCM) and to this solution a mixture of $10 \%$ trifluoroacetic acid (TFA) in DCM (4 mL) was slowly added, and the reaction mixture was stirred for $1 \mathrm{~h}$ at room temperature. The solvent was condensed under reduced pressure and then re-dissolved in THF, converted to the corresponding hydrochloric salt and precipitated in ethanol (EtOH)/1,4-Dioxane 4:1. The solid was filtered, washed and then dried in vacuo $\left(25^{\circ} \mathrm{C} / 38 \mathrm{mmHg}\right)$ over $\mathrm{KOH}$. The yield (\%) of each product was as following: $\mathrm{R}^{\prime}=\mathrm{H}, \mathrm{m}=1: 75 \% ; \mathrm{H}, \mathrm{m}=2: 74 \% ; \mathrm{H}, \mathrm{m}=3: 74 \% ; \mathrm{H}, \mathrm{m}=4: 74 \% ; \mathrm{H}$, $\mathrm{m}=5: 72 \% ; \mathrm{CH}_{3}, \mathrm{~m}=1: 70 \% ; \mathrm{CH}\left(\mathrm{CH}_{3}\right)_{2}, \mathrm{~m}=1: 72 \% ; \mathrm{CH}_{2} \mathrm{CH}\left(\mathrm{CH}_{3}\right)_{2}, \mathrm{~m}=1: 72 \% ; \mathrm{CH}\left(\mathrm{CH}_{3}\right) \mathrm{CH}_{2} \mathrm{CH}_{3}$, $\mathrm{m}=1: 70 \% ; \mathrm{CH}_{2}\left(\mathrm{C}_{6} \mathrm{H}_{5}\right)$ and $\mathrm{m}=1: 70 \%$.

\subsubsection{General Protocol for the Synthesis of Resin-bound Bis(aminoalkyl)dithiols}

Trityl(Trt) resin $(0.3 \mathrm{mmol}, 0.3 \mathrm{~g})$ was suspended in a plastic syringe equipped with porous polypropylene frit and washed with DCM ( $3 \mathrm{~min} \times 1 \mathrm{~min}$ ) and bis(aminoalkyl)dithiol (0.6 mmol, $\mathrm{R}^{\prime}=\mathrm{H}, \mathrm{m}=1: 0.19 \mathrm{~g} ; \mathrm{H}, \mathrm{m}=2: 0.20 \mathrm{~g} ; \mathrm{H}, \mathrm{m}=3: 0.21 \mathrm{~g} ; \mathrm{H}, \mathrm{m}=4: 0.22 \mathrm{~g} ; \mathrm{H}, \mathrm{m}=5: 0.26 \mathrm{~g} ; \mathrm{CH}_{3}, \mathrm{~m}=$ 1: $0.20 \mathrm{~g} ; \mathrm{CH}\left(\mathrm{CH}_{3}\right)_{2}, \mathrm{~m}=1: 0.22 \mathrm{~g} ; \mathrm{CH}_{2} \mathrm{CH}\left(\mathrm{CH}_{3}\right)_{2}, \mathrm{~m}=1: 0.23 \mathrm{~g} ; \mathrm{CH}\left(\mathrm{CH}_{3}\right) \mathrm{CH}_{2} \mathrm{CH}_{3}, \mathrm{~m}=1: 0.23 \mathrm{~g}$; $\mathrm{CH}_{2}\left(\mathrm{C}_{6} \mathrm{H}_{5}\right)$ and $\mathrm{m}=1: 0.25 \mathrm{~g}$ ) dissolved in $3 \mathrm{~mL}$ of DCM and $\mathrm{N}, \mathrm{N}$-diisopropylethylamine (DIPEA; $1.2 \mathrm{mmol}, 0.21 \mathrm{~mL}$ ) was added and the resin was shaken for $3 \mathrm{~h}$ at room temperature. DCM was filtered and the resin was washed with DCM $(1 \mathrm{~min} \times 2 \mathrm{~min}), \mathrm{DCM} / \mathrm{methanol}(\mathrm{MeOH}) / \mathrm{DIPEA}(85: 10: 5 ; 3 \mathrm{~min}$ $\times 15 \mathrm{~min}$ ), $\mathrm{N}$-methyl-2-pyrrolidone (NMP; $5 \mathrm{~min} \times 2 \mathrm{~min}$ ), isopropyl alcohol (iPrOH; $2 \mathrm{~min} \times 5 \mathrm{~min}$ ) and DEE ( $4 \mathrm{~min} \times 2 \mathrm{~min}$ ). The final resin was dried by suction in air for $15 \mathrm{~min}$ and further dried for $24 \mathrm{~h}$ in vacuo $\left(25^{\circ} \mathrm{C} / 0.5 \mathrm{mmHg}\right)$ over $\mathrm{KOH}$ and stored at $4{ }^{\circ} \mathrm{C}$.

\subsubsection{Solid-Phase Peptide Assembly, General Protocol}

Solid-phase peptide synthesis was carried out manually in plastic syringes equipped with porous polypropylene frits at room temperature, using the fluorenylmethoxycarbonyl (Fmoc)/tert-butyl $\left({ }^{\mathrm{t}} \mathrm{Bu}\right)$ strategy $[21,23]$.

Pre-Activation of Fmoc-Amino Acids and (Fmoc-Aminothiol)Carboxylic Acids

The Fmoc-amino acid or the (Fmoc-aminothiol)carboxylic acid $(4.5 \mathrm{mmol})$ and 1-hydroxybenzotriazole hydrate (HOBt; $5.8 \mathrm{mmol})$ were dissolved in NMP $(4.5 \mathrm{~mL})$ and cooled to $5{ }^{\circ} \mathrm{C}$. Then, diisopropylcarbodiimide (DIC; $5.0 \mathrm{mmol}$ ) was added and the mixture was stirred for $15 \mathrm{~min}$ at $5{ }^{\circ} \mathrm{C}$.

Coupling of Fmoc-Amino Acids and (Fmoc-Aminothiol)Carboxylic Acids

The solution of the pre-activated amino acid (the above paragraph) was added to the resin-bound amino-acid or peptide $(5.0 \mathrm{~g}$, loading $0.3 \mathrm{mmol} / \mathrm{g}$ ) and was shaken for $3 \mathrm{~h}$ at room temperature. A sample was taken to check the reaction completion by Kaiser test. In case of incomplete coupling (positive Kaiser test) recoupling was performed with a fresh solution of activated amino acid (6 mmol). 
Fmoc-Group Removal and Fmoc-Removal Test

The resin-bound Fmoc-protected amino acids or peptides were treated twice with $25 \%$ piperidine in NMP ( $25 \mathrm{~mL}$ ) for $30 \mathrm{~min}$ at room temperature. To check the completion of the $\mathrm{N}$-Fmoc removal, $25 \%$ piperidine in NMP $(20 \mu \mathrm{L})$ was added to a resin probe (approx. $2 \mathrm{mg}$ ) and the mixture was heated for $5 \mathrm{~min}$ at $100{ }^{\circ} \mathrm{C}$. From the resulting solution $10 \mu \mathrm{L}$ were spotted on a TLC plate and checked under a UV-lamp for UV-absorbing material. Alternatively, the solution was injected on HPLC and the Fmoc-material produced and released into solution was quantified at $265 \mathrm{~nm}$. If the $N$-Fmoc removal test remained positive (violet spot under UV) the piperidine treatment was prolonged or repeated until achieving negative test. The resin was filtered and washed with NMP $(\times 5)$, DCM $(\times 3)$, DEE $(\times 2)$ and dried in vacuo $\left(25^{\circ} \mathrm{C} / 0.5 \mathrm{mmHg}\right)$, otherwise it was used directly to the next step.

\subsubsection{General Procedure for the Loading of 2-Chlorotrityl(Cltr) Resin with Halo Acids}

To a suspension of $1 \mathrm{~g}$ Cltr resin (1.5-1.9 mmol chloride/gr resin) in $10 \mathrm{~mL}$ of DCM, DIPEA $(2 \mathrm{mmol})$ and the halo acid $(1.5 \mathrm{mmol})$ were added. The resulting mixture was left to react for $20 \mathrm{~min}$ at $25^{\circ} \mathrm{C}$. The resin was filtered, suspended in $20 \mathrm{~mL}$ of a DCM/MeOH/DIPEA (80:15:5) mixture and was shaken for $1 \mathrm{~h}$ at $25^{\circ} \mathrm{C}$. The resin was filtered and washed once more with the above mixture, and then with NMP $(5 \mathrm{~mL} \times 10 \mathrm{~mL}), \mathrm{DCM}(3 \mathrm{~mL} \times 10 \mathrm{~mL})$, diethylether (DEE; $3 \mathrm{~mL} \times 5 \mathrm{~mL})$ and dried in vacuo $\left(25^{\circ} \mathrm{C} / 0.5 \mathrm{mmHg}\right)$, otherwise it was used directly to the next step. The loading of the resins was determined by GC analysis after cleavage of the haloacids by treatment of resin probes with $3 \%$ trifluoroacetic acid (TFA) in DCM for $30 \mathrm{~min}$ at $25^{\circ} \mathrm{C}$.

\subsubsection{General Procedure for the Synthesis of Resin-Bound Haloacylated Peptides}

Halo acid (three-fold molar excess over the resin bound peptide) was dissolved in NMP. The solution was cooled on ice bath and then DIC ( 3 mol equiv.) was added. The activated halo acid was added to the resin-bound peptide and allowed to react for $1-3 \mathrm{~h}$ at $25^{\circ} \mathrm{C}$. The resin was filtered and washed with NMP $(\times 5)$, DCM $(\times 3), \mathrm{DEE}(\times 2)$ and dried in vacuo $\left(25^{\circ} \mathrm{C} / 0.5 \mathrm{mmHg}\right)$, otherwise it was used directly to the next step.

3.3.6. General Procedure for the Condensation of N-Fmoc Aminothiols or N-Fmoc Thiol-Peptides with Resin-Bound Haloacids

The N-Fmoc aminothiol (two-fold molar excess over the resin-bound haloacid) or the N-Fmoc thiol-peptide (two-fold molar excess over the resin-bound haloacylated peptide fragment) was dissolved in the highest possible concentration in NMP and DIPEA (2.2 equiv.). This solution was added to the dry resin without pre-swelling and the reaction was left for 1-12 $\mathrm{h}$ at room temperature. The resin was filtered and washed with $\mathrm{NMP}(\times 5), \mathrm{DCM}(\times 3), \mathrm{DEE}(\times 2)$ and dried in vacuo $\left(25^{\circ} \mathrm{C} / 0.5 \mathrm{mmHg}\right)$, otherwise it was used directly to the next step.

\subsubsection{General Procedure for the Cleavage of Thiol-Peptides from Trityl(Trt) Resin}

Method A:

Resin-bound bis(aminoalkyl)dithiol-peptides $(0.2 \mathrm{mmol})$ were treated with DTT (10 equiv.) in NMP for $12 \mathrm{~h}$ at room temperature. The resin was filtered and washed twice with NMP and then subjected to an extraction process in $\mathrm{DEE} / \mathrm{H}_{2} \mathrm{O}$. The organic layer was collected, dried over $\mathrm{Na}_{2} \mathrm{SO}_{4}$, filtered and condensed under reduced pressure.

Method B:

Resin-bound bis(aminoalkyl)dithiol-peptides $(0.2 \mathrm{mmol})$ were treated with TES (10 equiv.) in $\mathrm{DCM}$ for $12 \mathrm{~h}$ at room temperature. The resin was filtered and washed twice with DCM. The combined 
filtrates were concentrated on a rotary evaporator and to the residue DEE was added. The resulting solid was filtered, washed with DEE $(\times 4)$ and dried in vacuo $\left(25^{\circ} \mathrm{C} / 0.5 \mathrm{mmHg}\right)$.

\subsubsection{General Procedure for the Cleavage of Thiol-Peptides from 4-Methoxytrityl(Mmt) Resin}

A cleavage solution of 1.1\% TFA in DCM/TES (95:5) $(7 \mathrm{~mL})$ was added on $0.5 \mathrm{~g}$ of resin and the mixture was stirred magnetically at room temperature. The resin was filtered and washed twice with $5 \mathrm{~mL}$ of the cleavage solution. The combined filtrates were concentrated on a rotary evaporator and to the residue DEE was added. The resulting solid was filtered, washed with DEE $(\times 4)$ and dried in vacuo $\left(25^{\circ} \mathrm{C} / 0.5 \mathrm{mmHg}\right)$.

3.3.9. General Procedure for the Cleavage of Peptides and Thioether Containing Peptide Fragments from 2-Chlorotrityl(Cltr) Resin

A cleavage solution of 1.1\% TFA in DCM/TES (95:5) $(7 \mathrm{~mL})$ was added on $0.5 \mathrm{~g}$ of resin and the mixture was stirred magnetically at room temperature. The resin was filtered and washed twice with $5 \mathrm{~mL}$ of the cleavage solution. The combined filtrates were concentrated on a rotary evaporator and to the residue DEE was added. The resulting solid was filtered, washed with DEE $(\times 4)$ and dried in vacuo $\left(25^{\circ} \mathrm{C} / 0.5 \mathrm{mmHg}\right)$.

\section{Conclusions}

Besides classical step-by-step synthesis, the convergent solid phase peptide synthesis (CSPPS) was used for the preparation of complex and difficult peptides and small proteins.

Peptides where the amide bond is replaced by its $\mathrm{CH}_{2}-\mathrm{S}$ isostere (thioether containing peptides) are very important peptide mimetics. Thus, we were interested in the synthesis of thioether containing peptides by convergent methods.

Comparing the methods discussed, route C (Scheme 3) offers significant advantages, over routes $A$ and $B$, for the preparation of thioether containing peptides, mainly because the condensation of the thiol-peptide fragment 20 with the resin-bound bromoacetyl peptide $\mathbf{1 2}$ proceeds faster than: (i) the use of the thioether containing building block 8 in SPPS (Scheme 1; route A), or (ii) the condensation of the thioether containing peptide 9 with the peptide fragment $\mathbf{1 0}$ (Scheme 1; route A) or (iii) the condensation of the thiol-containing peptide fragment 14 with the peptide fragment 15 (Scheme 2; route $\mathrm{B})$.

Regarding the synthesis of the thiol-peptide fragment 20, in case that acid sensitive (cleaved under acidic solutions $\leq 1 \%$ TFA) amino acid side chain protecting groups are needed in the peptide sequence, we suggest its synthesis through reductive cleavage from resin 19, instead of its acidic cleavage from resin 18 (by which the acid labile protecting group would be cleaved).

In contrary, routes $\mathrm{B}$ and $\mathrm{C}$, which were based on the synthesis of the resin-bound haloacylated peptide 12, have to be avoided when the sequence of 12 contains various strong nucleophiles, which may react with the haloacetyl moiety. This is a well-known problem for bromoacetylated-Met-peptides and we proved that bromoacetylated-Pro-peptides also suffered from instability issues, by their conversion to the corresponding diketopiperazine peptide derivatives. In this case, route A should be preferred, as in this route the thioether formation is performed on the resin-bound esterified haloacid 5, thus, amino acids have not yet been introduced into the peptide sequence, avoiding the nucleophilic attack on the haloacetyl moiety by the nucleophilic groups that are present in the peptide chain of routes $\mathrm{B}$ and $C$.

Supplementary Materials: The following are available online, Figure S1: Analytical hplc of thioether containing peptides 16 and 17. Figure S2: Analytical hplc of Fmoc-Leu-alaninothiol prepared by coupling of Fmoc-Leu-OH on the Trt-resin $19\left(\mathrm{~m}=1 ; \mathrm{R}^{\prime}=\mathrm{CH}_{3}\right)$ and subsequent cleavage by DTT (A) and TES (B). Figure S3: Analytical hplc (A) and ESI-MS analysis (B) of thiol-peptide 21 (ProTa (69-75) derivative), and hplc analytical hplc (C) and ESI-MS analysis (D) of thiol-peptide 22 (Hir (11-18) derivative), synthesized on Trt-resin $19\left(\mathrm{R}^{\prime}=\mathrm{CH}_{3}(\mathbf{2 1})\right.$; $-\mathrm{CH}_{2}-\mathrm{Ph}(\mathbf{2 2})$ ). Figure S4: Analytical hplc of 26. Figure S5: Analytical hplc during reaction of 27 and 28 at 2 h (a) and 24 h (b). 
The reaction process was monitored by following the peaks of the desired product $\mathbf{3 0}$ and the un-reacted $\mathbf{3 1}$ after their cleavage from resin; ESI-MS analysis of 30 (c).

Author Contributions: K.B. Conceptualization; K.B., D.G., S.M., C.K. designed the synthetic methodologies; S.M. and C.K. performed the experiments; K.B. and S.M. wrote the manuscript; All authors have read and agreed to the published version of the manuscript.

Funding: This research received no external funding.

Acknowledgments: The authors acknowledge C.B.L. Patras S.A., Patras, Greece, for financial support.

Conflicts of Interest: The authors declare no conflict of interest.

\section{References}

1. Vlieghe, P.; Lisowski, V.; Martinez, J.; Khrestchatisky, M. Synthetic therapeutic peptides: Science and market. Drug Discov. Today 2010, 15, 40-56. [CrossRef] [PubMed]

2. Avan, I.; Hall, C.D.; Katritzky, A.R. Peptidomimetics via modifications of amino acids and peptide bonds. Chem. Soc. Rev. 2014, 43, 3575-3594. [CrossRef] [PubMed]

3. Qvit, N.; Rubin, S.J.S.; Urban, T.J.; Mochly-Rosen, D.; Gross, E.R. Peptidomimetic therapeutics: Scientific approaches and opportunities. Drug Discov. Today 2017, 22, 454-462. [CrossRef] [PubMed]

4. Ahn, J.M.; Boyle, N.A.; MacDonald, M.T.; Janda, K.D. Peptidomimetics and peptide backbone modifications. Mini Rev. Med. Chem. 2002, 2, 463-473. [CrossRef] [PubMed]

5. Marik, J.; Bennettova, B.; Tykva, R.; Budesinsky, M.; Hlavacek, J. Synthesis and effect of shortened oostatic decapeptide (TMOF) analogs with isosteric structures on reproduction of Neobellieria bullata. J. Pept. Res. 2001, 57, 401-408. [CrossRef] [PubMed]

6. Roubini, E.; Laufer, R.; Gilon, C.; Selinger, Z.; Roques, B.; Chorev, M. Pseudopeptide analogues of substance $\mathrm{P}$ and leucine enkephalinamide containing the psi $(\mathrm{CH} 2 \mathrm{O})$ modification: Synthesis and biological activity. J. Med. Chem. 1991, 34, 2430-2438. [CrossRef] [PubMed]

7. Qian, J.; Coy, D.; Jiang, N.; Gardner, J.; Jensen, R. Reduced peptide bond pseudopeptide analogues of substance P. A new class of substance P receptor antagonists with enhanced specificity. J. Biol. Chem. 1989, 264, 16667-16671. [PubMed]

8. TenBrink, R.E.; Pals, D.T.; Harris, D.W.; Johnson, G.A. Renin inhibitors containing psi[CH2O] pseudopeptide inserts. J. Med. Chem. 1988, 31, 671-677. [CrossRef]

9. Nicolaides, E.D.; Tinney, F.J.; Kaltenbronn, J.S.; Repine, J.T.; DeJohn, D.A.; Lunney, E.A.; Roark, W.H.; Marriott, J.G.; Davis, R.E.; Voigtman, R.E. Modified di- and tripeptides of the C-terminal portion of oxytocin and vasopressin as possible cognition activation agents. J. Med. Chem. 1986, 29, 959-971. [CrossRef]

10. Spatola, A.F. Peptide backbone modifications: A structure-activity analysis of peptides containing amide bond surrogates, conformational constraints, and related backbone replacements. In Chemistry and biochemistry of amino acids, peptides, and proteins; Weinstein, B., Ed.; Marcel Dekker Inc.: New York, NY, USA, 1983; Volume 7, pp. 267-357.

11. Hann, M.; Sammes, G.; Kennewell, D.; Taylor, B.J. On the double bond isostere of the peptide bond: Preparation of an enkephalin analogue. J. Chem. Soc., Perkin Trans. 1 1982, 307-314. [CrossRef]

12. Hudson, D.; Kenner, G.W.; Sharpe, R.; Szelke, M. Methionine enkephalin and isosteric analogues I. Synthesis on a phenolic resin support. Int. J. Pept. Protein. Res. 1979, 14, 177-185. [CrossRef] [PubMed]

13. Rubini, E.; Gilon, C.; Selinger, Z.; Chorev, M. Synthesis of isosteric methylene-oxy pseudodipeptide analogues as novel amide bond surrogate units. Tetrahedron 1986, 42, 6039-6045. [CrossRef]

14. Hlaváček, J.; Marcová, R.; Ježek, R.; Slaninová, J. Utilization of some non coded amino acids as isosters of peptide building blocks. Amino Acids 1996, 11, 367-377. [CrossRef]

15. Campiglia, P.; Aquino, C.; Bertamino, A.; Sala, M.; Gomez-Monterrey, I.M.; Novellino, E.; Grieco, P. Novel route in the synthesis of $\psi\left[\mathrm{CH}_{2} \mathrm{NH}\right]$ amide bond surrogate. Tetrahedron Lett. 2008, 49, 731-734. [CrossRef]

16. Scognamiglio, P.L.; Morelli, G.; Marasco, D. Synthetic and structural routes for the rational conversion of peptides into small molecules. Methods Mol. Biol. 2015, 1268, 159-193. [PubMed]

17. Sasaki, Y.; Coy, D.H. Solid phase synthesis of peptides containing the $\mathrm{CH} 2 \mathrm{NH}$ peptide bond isostere. Peptides 1987, 8, 119-121. [CrossRef]

18. Stawikowski, M.; Fields, G.B. Introduction to peptide synthesis. Curr. Protoc. Protein Sci. 2002. [CrossRef] 
19. Albericio, F.; Lloyd-Williams, P.; Giralt, E. Convergent solid-phase peptide synthesis. Methods Enzym. 1997, $289,313-336$.

20. Góngora-Benítez, M.; Tulla-Puche, J.; Albericio, F. Handles for Fmoc solid-phase synthesis of protected peptides. Acs Comb. Sci. 2013, 15, 217-228. [CrossRef]

21. Barlos, K.; Gatos, D. Convergent peptide synthesis. In Fmoc Solid Phase Peptide Synthesis—A Practical Approach; Chan, W.C., White, P.D., Eds.; Oxford University Press: New York, NY, USA, 2001; pp. 215-228.

22. Nishiuchi, Y.; Nishio, H.; Inui, T.; Bódi, J.; Kimura, T. Combined solid-phase and solution approach for the synthesis of large peptides or proteins. J. Pept. Sci. 2000, 6, 84-93. [CrossRef]

23. Amblard, M.; Fehrentz, J.-A.; Martinez, J.; Subra, G. Methods and protocols of modern solid-phase peptide synthesis. Mol. Biotechnol. 2006, 33, 239-254.

24. Athanassopoulos, P.; Barlos, K.; Gatos, D.; Hatzi, O.; Tzavara, C. Application of 2-chlorotrityl chloride in convergent peptide synthesis. Tetrahedron Lett. 1995, 36, 5645-5648. [CrossRef]

25. Barlos, K.; Gatos, D.; Kallitsis, J.; Papaphotiu, G.; Sotiriu, P.; Wenqing, Y.; Schäfer, W. Darstellung geschützter peptid-fragmente unter einsatz substituierter triphenylmethyl-harze. Telrahedron Lett. 1989, 30, 3943-3946. [CrossRef]

26. Behrendt, R.; White, P.; Offer, J. Advances in Fmoc solid-phase peptide synthesis. J. Pept. Sci. 2016, $22,4-27$. [CrossRef]

27. Lloyd-Williams, P.; Albericio, R.; Giralt, E. Convergent solid-phase peptide synthesis. Tetrahedron 1993, 49, 11065-11133. [CrossRef]

28. Benz, H. The role of solid-phase fragment condensation (SPFC) in peptide synthesis. Synthesis 1994, 4, 337-358. [CrossRef]

29. Mourtas, S.; Katakalou, C.; Nicolettou, A.; Tzavara, C.; Gatos, D.; Barlos, K. Resin-bound aminothiols: Synthesis and application. Tetrahedron Lett. 2003, 44, 179-182. [CrossRef]

30. Englebretsen, D.R.; Garnham, B.; Alewood, P.F. A cassette ligation strategy with thioether replacement of three Gly-Gly peptide bonds: Total chemical synthesis of the 101 residue protein early pregnancy factor [psi(CH2S)28-29,56-57,76-77]. J. Org. Chem. 2002, 67, 5883-5890. [CrossRef]

31. Robey, F.A.; Fields, R.L. Automated synthesis of N-bromoacetyl-modified peptides for the preparation of synthetic peptide polymers, peptide-protein conjugates, and cyclic peptides. Anal. Biochem. 1989, 177, 373-377. [CrossRef]

32. Robey, F.A. Bromoacetylated synthetic peptides. Starting materials for cyclic peptides, peptomers, and peptide conjugates. Methods Mol. Biol. 1994, 35, 73-90.

33. Marks, R.H.; Miller, R.D. Chemical modification of methionine residues in azurin. Biochem. Biophys. Res. Commun. 1979, 88, 661-667. [CrossRef]

Sample Availability: Samples of all compounds are available.

(C) 2020 by the authors. Licensee MDPI, Basel, Switzerland. This article is an open access article distributed under the terms and conditions of the Creative Commons Attribution (CC BY) license (http://creativecommons.org/licenses/by/4.0/). 